\title{
EFFECT OF DIFFERENT DIETS ON SURVIVAL AND GROWTH OF STRIPED MURREL FRY CHANNA STRIATUS
}

\author{
D. Kumar \& M.A. Haniffa*
}

\begin{abstract}
Tubifix, Chiranomus, Beef liver, mosquito larvae and plankfon used as feed were tested as diets in the early lanol growth of Channa striatus fry over a 45 days period. Among all the food types Chironomus was found to produce the best growth results followed by tubifix, while other food types yielded poor results.
\end{abstract}

Key words: Channa striatus, growh, nutrition, dief

\section{Introduction}

Various dry feed formulae have been investigated as possible substitutes of live food for larval development (Appelbaum and Dor, 1978; Dabrowski 1983; 1984). In recent years suitability of various dry feed formulae has been investigated for the rearing of Cyprinid and catfish larvae (Bryant and Matty 1981; Msiska, 1981; Hecht and Viljoen, 1982). However it has been shown that formulated compound diets do not provide optimal larval growth when used exclusively as larval food, especially during the early larvae stages of Cyprinids and catfish (Hogendoorn, 1980; Dabrowski 1984; prinsloo and Schoonbee, 1986), therefore live food provide

* Centre for Aquaculture Research and Extention (CARE), St. Xavier's College (Autonomus), Palayankottai, Tirunelveli. E-mail: devadosskumar@yahoo.co.in. 
a substantial availability of protein and other essential nutrients (Jhingran, 1975; Ahmed, 1994; Thakur. 1978; Munnet, 1979) provided some basic information on the feeding of $C$. batrachus fry. However development of suitable feed for rearing Channa striatus fry is lacking. It is therefore important to study the efficacy of a few selective feeds.

Channa striatus snakehead is an air breathing, and carnivorous in nature. They are widely distributed in Africa and Asia. It is having high market due to its taste and flesh. They support economically important fisheries and aquaculture industry in many Asian countries (Ling 1979, Chen 1990). Among murrels C. striatus forms a significant role in capture fisheries of India. Characteristics of this fish that make it desirable cultivable food fish include rapid growth and the ability of the fish to store and use atmospheric oxygen for respiration in waters with low dissolved oxygen and they can withstand higher stocking densities also. It has been estimated that out of 18,000 t of marketable surplus air breathing fishes caught from natural resources in India, murrels account for nearly 12,000 + (Jhingran 1975) with major part of them constituted by Channa marulius, Channa striatus and Channa punctatus. However, murrel culture is not practised in a well-defined way in India due to several reasons. One of these is that there are no seed supply / sales centre for murrels in country.

The fish farmers therefore depend on wild collection, which are unpredictable. Further, the rearing of hatchlings, post lawae and fry of $C$. striatus is a complicated process unlike the raising of carp fry, which has been standardized in some extent. Recently attempis have been made on larval nutrition of Channa striatus by (Qin et al. (1997), Samantaray and Mohanty (1997). But these authors have provided formulated pelleted feeds (instead of live feed) to the larvae resulting in poor survival and growth. In the present study a comparison is made on the growth of $C$. striatus larvae using tubifix, Chironomus, plankton and Beef liver and mosquito larvae as two alternative live foods during the early larval growth phase of this species.

\section{Materials and Method}

Channa striatus fry (length: $3.57+0.05 \mathrm{~cm}$, weight $0.425+0.03 \mathrm{~g}$ ) were collected from (CARE) earthen pond and acclimatized in the cement tanks for a period of one week; during this period they were fed with plankton soup. They were grouped into 5 batches and stocked for 10 individual for each treatment with three replicates and reared in plastic troughs. (Capacity 15/Lt).

Water quality parameters viz., femperature $29^{\circ} \mathrm{C} \pm 1{ }^{\circ} \mathrm{C}$ dissolved oxygen $6.1-6.6$ $\mathrm{mg} / \mathrm{lt}$ and $\mathrm{pH} 7.5-8.25$ were recorded throughout the study. They were fed with 
tubifix, Chrionomus larvae, beef liver, mosquito larvae and plankton soup twice / day (1 $1.00 \mathrm{hrs}, 13.00 \mathrm{hrs}$ ) ad libitum. The feeding trial was continued for a period of 45 days. Water was changed everyday with minimal disturbance to the experimental animals full nos. the length and weight were recorded once in every fortnight, the growth parameters viz, weight gain (\%), specific growth rate and (\%/day) and survival (\%) were estimated as Weight gain (\%/day)=final mean weight-initial mean weight / initial mean weight / days $\times 100 ;$ SGR (\%/day) =final mean log weight-initial mean log weight/days $\times 100$; Survival $(\%)=$ Final total no. of fish/ Initial total no. of fish $\times 100$. After the completion of the experiment five fishes were sacrificed for the proximate composition estimations.

\section{Results}

All foods were readily accepted from the start of feeding. The beef liver was taken by larvae from the bottom of the trough, whereas zooplankton, mosquito larvae in the mid water of the trough and the tubifix, Chironomus taken by the larvae from the bottom. The body composition of the fish fed on different diets and growth parameter was presented in table 1, 2. From that tables, body protein, carbohydrate and lipid of the fish is higher in the diet of D2 and followed by other diets groups. And Fig 1 shows the Specific growth rate and relative growth rate and growth rate of Channa striatus fry.

Table 1. Growth and Survival of Channa striatus fry fed on different types of diets

\begin{tabular}{|l|l|l|l|l|l|}
\hline & \multicolumn{5}{|c|}{ Diets } \\
\cline { 2 - 6 } & Tubifix & Blood worm & Beef liver & Mosquito & Plankton \\
\hline $\begin{array}{l}\text { Initial } \\
\text { length (cm) }\end{array}$ & $3.506 \pm .024$ & $3.603 \pm .018$ & $3.586 \pm .109$ & $3.66 \pm .141$ & $3.523 \pm .053$ \\
\hline $\begin{array}{l}\text { Initial } \\
\text { weight (g) }\end{array}$ & $.406 \pm .020$ & $.390 \pm .031$ & $.425 \pm .041$ & $.443 \pm .040$ & $.463 \pm .026$ \\
\hline $\begin{array}{l}\text { Final } \\
\text { length (cm) }\end{array}$ & $6.918 \pm .072$ & $7.66 \pm .082$ & $6.69 \pm .052$ & $6.512 \pm .305$ & $6.054 \pm .069$ \\
\hline $\begin{array}{l}\text { Final } \\
\text { weight (g) }\end{array}$ & $3.267 \pm .020$ & $3.948 \pm .056$ & $2.85 \pm .081$ & $2.11 \pm .082$ & $2.126 \pm .010$ \\
\hline Duration & 45 & 45 & 45 & 45 & 45 \\
\hline SGR\% & $1.383 \pm .049$ & $1.529 \pm .052$ & $1.22 \pm .097$ & $1.112 \pm .081$ & $1.082 \pm .045$ \\
\hline $\begin{array}{l}\text { Weight } \\
\text { gain }\end{array}$ & $\begin{array}{l}705.64 \pm \\
41.805\end{array}$ & $\begin{array}{l}919.00 \pm \\
62.324\end{array}$ & $\begin{array}{l}578.15 \pm \\
74.78\end{array}$ & $\begin{array}{l}380.20 \pm \\
38.37\end{array}$ & $\begin{array}{l}360.185 \pm \\
26.47\end{array}$ \\
\hline
\end{tabular}




\begin{tabular}{|l|l|l|l|l|l|}
\hline RGR\% & $7.056 \pm .418$ & $9.162 \pm .70$ & $5.78 \pm .747$ & $3.801 \pm .382$ & $3.601 \pm .264$ \\
\hline $\begin{array}{l}\text { ADG } \\
\text { (g/day) }\end{array}$ & $.0723 \pm .0004$ & $.0874 \pm .0013$ & $.0629 \pm .0016$ & $.0466 \pm .001$ & $.0472 \pm .0002$ \\
\hline $\begin{array}{l}\text { Growth } \\
\text { rate (\%) }\end{array}$ & $39.39 \pm .301$ & $40.55 \pm .299$ & $37.79 \pm .600$ & $35.56 \pm .760$ & $35.18 \pm .551$ \\
\hline Survival\% & $90 \pm 14.14$ & $96.66 \pm 4.714$ & $76.66 \pm 4.714$ & $66.66 \pm 4.714$ & $73.33 \pm 9.428$ \\
\hline
\end{tabular}

Table 2. Body composition of the Channa striatus fry fed on different diets

\begin{tabular}{|l|r|r|r|r|r|r|}
\hline & \multicolumn{7}{|c|}{ Diets } \\
\cline { 2 - 7 } & \multicolumn{1}{|c|}{ Initial } & \multicolumn{1}{c|}{ D1 } & \multicolumn{1}{c|}{ D2 } & \multicolumn{1}{c|}{ D3 } & \multicolumn{1}{c|}{ D4 } & \multicolumn{1}{c|}{ D5 } \\
\hline Protein \% & 14.01 & 15.14 & 16.28 & 15.68 & 14.21 & 14.32 \\
\hline Carbohydrate \% & .88 & .98 & 1.01 & .88 & .94 & .93 \\
\hline Lipid \% & 3.14 & 3.16 & 3.06 & 2.94 & 3.01 & 2.84 \\
\hline Ash \% & 3.2 & 3.5 & 3.9 & 2.8 & 3.2 & 3.4 \\
\hline Moisture\% & 76.14 & 74.1 .5 & 73.48 & 75.14 & 74.28 & 75.01 \\
\hline
\end{tabular}

D1-Tubifix, D2-Chironomus, D3-Beef liver, D4-Mosquito, D5-Plankton

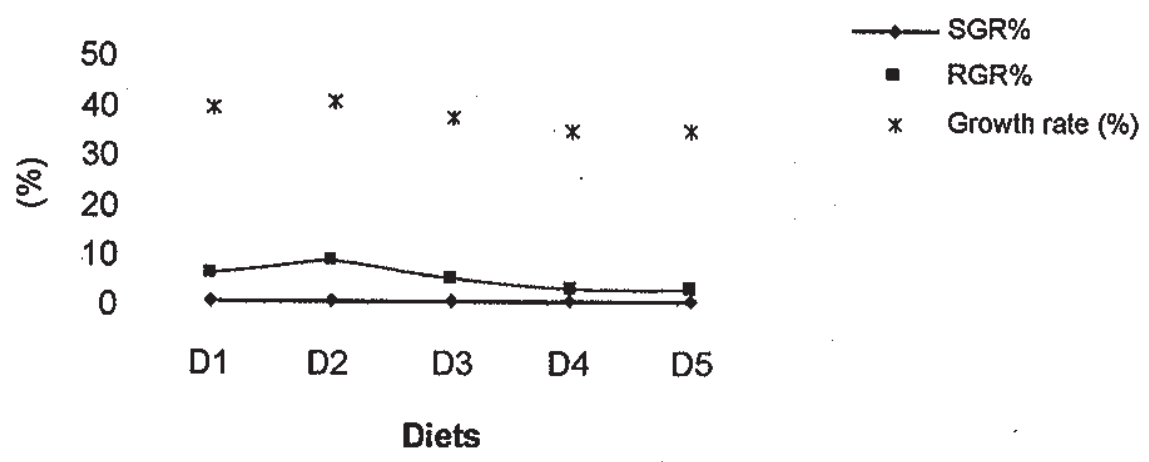

Fig 1. Effect of different diets on the growth performance of Channa striatus fry fed on different diets

Live food is regarded as the best for fishes, many crustacean, insect larvae. In present study the result revealed that the highest specific growth rate $(1.529 \% /$ day), was obtained in the individual fed with Chironomus (Table 1) followed by tubifix fed on $1.383 \%$ /day), beef liver (1.22\%/day), mosquito larvae (1.112\%/day) and plankton $(1.082 \% /$ day). The best weight gain was obtained by those fed on 
Chironomus larvae (919.00). And followed by (705.64) those fed on tubifix. The best survival rate $(96.66 \%$ ) was obtained in Channa striatus fed on Chironomus larvae whereas the lowest survival (73.33\%) were observed in those fed on plankton.

\section{Discussion}

The results showed that live food, in particular Chironomus larivae is a most desirable diet for the rearing of the Channa striatus larvae. The importance of artemia as live food (Hogendoorn, 1980; Msisko, 1981) is again confined by this investigation. However Prinsloo and Schoonbee (1986) observed zooplankton as best live food in comparison to commercial dry feed for the rearing of the silver carp and grass carp species over a period of 10-14 days; silver carp and grass carp larvae acquired relatively better growth with zooplankton as compared to commercial dry food. In our present study instead of zooplankton chironomus displayed superior growth and other parameter were recorded, due to the higher protein $61.17 \%$ and haem content of the Chironomus larvae. Qin, Fast, De Anda \& Weidenbach (1997) also developed a protocol for weaning lawal snake heads from live artemia to formulated feed, but grow out performance with formulated feed was not evaluated.

Live food is an important diet in the rearing of larvae of a member of fish species (Hogendoorn, 1980; Msiska, 1981; Stenson; 1982) indicated the importance of rotifer Brachionus plicatilis for mass larval rearing of fishes and stressed the value of the inclusion of rotifers in combination with artificial dry feeds for the optimum growth of Cyprinus carpio lanae. Matlak and Matlak (1976) indicated that rotifers are important food items of carp larvae during the first three weeks in nursery ponds. Zooplankton is the best larval food for a variety of fish larvae (Kilambi and Zdinak, 1982; Geiger 1983a, and Dabrowski 1984). The nutritional value of artemia for Cyprinus carpio lavae indicated good growth (Bryant and Matty 1981). A variety of dry foods were used for the rearing of C.carpio larvae (Appelbaum and Dor 1978; Hecht and Viliean 1982).

According to Cahu et al. (1998), larvae receiving live food also showed better survival and growth than larvae receiving artificial diets, sea bass Dicentrarchus labrax. Abi-Ayad and Kestemont (1994) observed the highest SGR in gold fish Carassius auratus larvae fed the mixed diets. Whereas the lowest SGR (1.325\%/ day) fed on plankton. Numbers of reports are available on lawal rearing, Mahseer larvae (Rai, 1990), also reported that larvae of Mahseer fed with plankton showed better growth when fed with other supplementary diets. In addition to the fry of katle Acrossocheilus hexagonolepis also showed better growth, when fed with $30 \%$ protein content with plankton soup (Rai, 1990). 
Malkotra and Munchi (1985) found that formulated feed might also be physically unsuitable for most first feeding fish larvae because large food particles that didn't pass down the gut could subject larvae to physical stress or physiological stress. The fish growth rate is generally related to availability and density of optimal food (Mittelbach 1981). Walleye growth increased after they switched their diets from zooplankton to chironomids (Fox et al 1989). But in our present study Chironomus larvae displayed superior growth fed with the Channa striatus fry is reported.

Dabrowski (1982) reported that many small fish larvae do not have the enzymes for digesting non-living diets. So we are applied different types of feeds. Artemia nauplia suitable for rearing of the young ones. Some relevant reports are available; Fluechter (1980) found that protein digestion enzymes in live Artemia nauplia were responsible for successful rearing of White fish (coregonus lavaretus) larvae.

\section{Conclusion}

Our present results strongly support the use of live food in the early larval growth phase of C.striatus larvae. So the blood worm is strongly recommended to the rearing of C.striatus larvae, it should not affect further development of the larvae.

\section{Acknowledgement}

The author is thankful to UGC for their financial support, and thankful to Principal Rev. Fr. Dr. A. Antonysamy, St. Xavier's College (Autonomous) Palayamkottai, Tirunelveli, for giving the lab facility to do this work, in St. Xavier's College Palayamkottai.

\section{References}

1. Abi-Ayad A. and P. Kestemont 1994. Comparison of the Nutritional Status of gold fish Carassius auratus larvae with live mixed or dry diet Aquaculture 128:163-176.

2. Ahmed, G.U. 1994, Effect of first food on the growth of African catfish (C. gariepinus) during the primary nursing phase. BAV. Res. Prog. 8:567-574.

3. Appelbaum, S. and U. Dor 1978. Zehntagige Anfutterung von Karpfenlarven (Cyprinus carpio) mit Trockenfutter auf Kommerzierller basis. Der Fischwirt, 28 (5): 25-26.

4. Bryant, P.L. and A.J. matty 1981. Adaptation of carp (Cyprinus carpio) larvae to artificial diets 1: Optimum feeding rate and adapation age for a commercial diet. Aquaculture,
23:275-286. 
5. Cahu, C, J.H. Zambonino Infante A.M. Escaffre, P. Bergot and S. Kaushik 1998. Perliminary results on sea bass (DicentrarChus labrax) larvae rearing with compound dief from first feeding. Comparison with carp (Cyprinus carpio) larvae, Aquaculture 169:1-7.

6. Chen, L.C. 1990, Snake head culture: 39-42. In. L.C. Chen (ed). Aquaculture in Taiwan. Blackwell scientific publication, London.

7. Dabrowski, K. 1982 Proteolytic enzyme activity decline in starving fish alevins and larvae Environ. Biol. Fish, 7:73-76.

8. Dabrowski, K. 1983. Comparative aspect of protein digestion and amino acid absorption in fish and other animals. Com. Biochem. Physiol: 74A:417-425.

9. Dabrowski, K. 1984. Influence of initial weight during the change from live to compound feed on the survival and growth of four cyprinids. Aquaculture 148:105-113.

10. Fluechter, 1. 1980. Review of the present knowledge of rearing white fish (Coregonidae) larvae, Aquaculture 19:191-208.

11. Fox M.G., Keast J. A., Swainson, R.J, 1989. The effect of fertilization regime on juvenile Walleye growth and Prey utilization in rearing Ponds. Environ. Bio. Fish 26:129-142.

12. Geiger, J.G. 1983a. Zooplankton production and manipulation in striped bass rearing pond. Aquaculture, 35:331-351.

13. Hecht, $\mathrm{Y}$. and $\mathrm{H}$. Vilioe, 1982. Observation on the suitability of various dry feeds for the commercial rearing of carp, Cyprinus carpio larvae in South Africa. Water SA, 8(1):58-65.

14. Hoogendoorn, H. 1980. Controlled propagation of the African catfish, Clariass lazera (C \& V). III: Feeding and growth of fry, Aquaculture, 21:233-241.

15. Jhingran, 1975. Fish and fisheries of India. Hindustan Publishing Corporation, $954 \mathrm{pp.}$

16. Kilambi, R.V. and A. Zdinak, 1982. Food intake and growth of hybrid carp (female carp, Ctenopharyngodon idella and male bighead, Aristichthys (Hypotalmichthys nobilis) fed on zooplankton and chara, J. Fish Biol., 21:63-67.

17. Ling, S.W., 1977., Snake head Ophiocephalus spp. Culture, pp. 60-64 In, S.W. Ling (ed) Aquaculture in South East Asia. A historical review. University of Washington Press, Seattle.

18. Malkotra, Y.R., Munshi. S. 1985. First Feeding and Survival of Aspido Pario Morar (Cyprinidae) Trans. AM. Fish. Soc. 114:286-290.

19. Matlak, J. and O. Matlaak, 1976. The natural food of carp fry (Cyprinus carpio). Acto. Hydrobiol., 18(3):203-228.

20. Mittelbach G.G., 1.981. Foraging efficiency and body size; A study of optimal diet and habitat use of blue gills, Ecology 62:1370-1386.

21. Msiska, O.V. 1981. Rearing of the fry of the African cattish Clarius lazera (C \& V) using live and artificial feed stuffs. Bamidgeh, 33:122-127.

22. Munnet, S.K. 1979. An experiment of feeding of magur, Clarius batrachus (linn). J. Inland Fish. Soc. India $11(2): 10-14$. 
23. Prinsloo, J.F. and J.H. Schoonbee, 1986. Comparison of the early larval growth rates of the Chinese silver carp Hypophthalmicthys nobilis using live and artificial Feed Water SA; 12(4):229-234.

24. Qin, J., Fast, A.N., De Anda D. \& Weidenbach R.P (1997) Growth and survival of larval snake head Channa striatus, fed different diets. Aquaculture 148:105-1 13.

25. Roi, A.k., 1990. Propagation of katle (Acrossocheilus hexagonolepis) and studies on food habits and growth of young ones in different dietary protein level. A project report submitted to International Development Research Centre (IDRC) Lalitpur, Nepal, Inland Fisheries Dev. Project, Harihar Bhawan, Pulchowk, 22p.

26. Samantarary K. and S.S. Mohanty (1997) inferactions of dietary levels of protein and energy on fingerling snakehead, Channa striatus, Aquaculture 156:(241-249).

27. Stenson, J.A.E. 1982. Fish impact on rotifer community structure. Hydrobiologia, 87:57-64.

28. Thakur, N.K., 1978. On the food of the air breathing catfish calias batrachus (Linn) occuring in wild water. Hydrobiologia, 63(3):421-431. 